\title{
HUBUNGAN ANTARA KEBIASAAN SARAPAN DENGAN KESEGARAN JASMANI DAN STATUS GIZI PADA ANAK SEKOLAH DASAR DI SD NEGERI PADANGSARI 02 BANYUMANIK
}

\author{
Rossa Kurnia Ethasari, Nuryanto*) \\ Program Studi Ilmu Gizi Fakultas Kedokteran Universitas Diponegoro \\ Jl.Dr.Sutomo No.18, Semarang, Telp (024) 8453708, Email : gizifk@ undip.ac.id
}

\begin{abstract}
Background. There are many elementary school students still haven't knew the benefit of breakfast and many of them often ignore having breakfast. Breakfast is useful for their physical fitness and nutritional status by improving nutrient needs. This study aims to know association of the habit of having breakfast with physical fitness and nutritional status in elementary school students.

Method. The research design is cross-sectional study. The subjects were 56 subjects of elementary school which were randomized. The data of habit of having breakfast was determined by food recall method $3 \times 24$ hour, physical fitness was determined by Harvard Step Test and the nutritional status was determined by z-score value BMI/age. Data were normally distributed and then analyzed by spearman rank test.

Result. Habit of breakfast mean was 4,28 \pm 1,84 times/week. Energy intake from breakfast mean was 34,01 $\pm 9,09$ percent. Physical fitness mean was 73,08 $\pm 8,81$ bpm. Z-score BMI/age mean was 0,88 $\pm 1,45$. The result shows that there is no association between the habit in breakfast with physical fitness $(p=0,372 ; r=0,045)$ and there is no association between the habit in breakfast with nutritional status $(p=0,080 ; r=0,190)$.
\end{abstract}

Conclusion. There is no association of the habit of breakfast with physical fitness and nutritional status.

Key word. Breakfast, physical fitness, the nutritional status

\section{ABSTRAK}

Latar Belakang : Masih banyak anak sekolah dasar (SD) yang belum tahu manfaat sarapan dan seringnya mengabaikan sarapan. Sarapan berguna untuk kesegaran jasmani dan status gizi yaitu melalui pemenuhan kebutuhan zat gizi. Penelitian ini bertujuan untuk mengetahui hubungan antara kebiasaan sarapan dengan kesegaran jasmani dan status gizi pada anak SD.

Metoda : Desain penelitian adalah cross-sectional. Subjek sebanyak 56 anak diperoleh dengan cara random sampling. Data yang dikumpulkan meliputi kebiasaan sarapan diperoleh dengan metode food recall $3 \times 24$ jam, kesegaran jasmani diperoleh dengan Harvard Step Test dan status gizi ditentukan berdasarkan pengukuran z-score IMT/U. Data dianalisis menggunakan uji rank spearman dengan melihat kenormalan data.

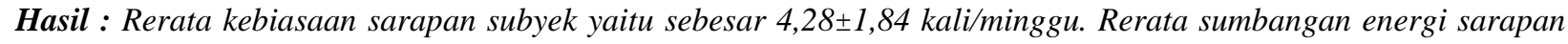

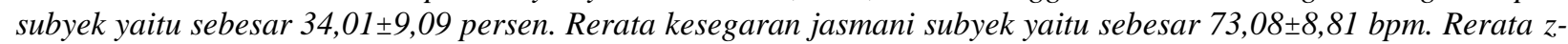

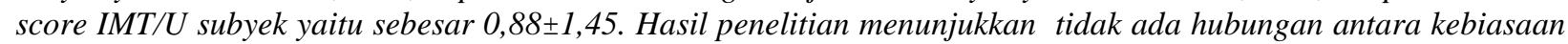
sarapan dengan kesegaran jasmani $(p=0,372, r=0,045)$. Tidak ada hubungan antara kebiasaan sarapan dengan status gizi $(p=0,080, r=0,190)$.

Simpulan : Tidak ada hubungan antara kebiasaan sarapan dengan kesegaran jasmani dan status gizi.

Kata Kunci : Sarapan, kesegaran jasmani, status gizi

\section{PENDAHULUAN}

Kebiasaan sarapan pada anak SD kurang baik, seperti seringnya mengabaikan sarapan. Sarapan sangat penting untuk anak SD karena dengan sarapan maka kebutuhan zat gizi untuk aktivitas mereka saat di sekolah dapat terpenuhi, dengan terpenuhinya kebutuhan zat gizi maka konsetrasi belajar juga meningkat dan masa pertumbuhannya juga tidak terganggu. Hal ini nanti juga akan berpengaruh terhadap performa akademiknya. ${ }^{1,2}$
Sarapan sebaiknya mengandung makanan sumber karbohidrat kompleks, protein, tinggi serat, rendah lemak, vitamin, mineral dan asam folat yang bertujuan untuk meningkatkan daya ingat anak saat belajar di sekolah. Selain itu energi dari sarapan untuk anak dianjurkan berkisar 20-25\% dari kebutuhan energi total dalam sehari yang dilakukan pada pagi hari. ${ }^{3,4}$

Sarapan dan kesegaran jasmani keduanya sangat penting dan saling menunjang satu sama lain manfaatnya. Kesegaran jasmani untuk anak SD itu penting karena dapat berpengaruh pada

${ }^{*}$ Penulis Penanggungjawab 
kemampuan intelektual dan kecerdasanya. Tanpa tubuh yang segar maka seorang siswa tidak mungkin dapat menerima pelajaran dengan baik, karena belajar membutuhkan keadaan yang sehat dan segar. Kesegaran jasmani akan didapat salah satunya dengan zat gizi yang cukup. ${ }^{5}$ Penelitian di SD Singosari Semarang menunjukkan hasil bahwa anak yang melakukan sarapan sebanyak $73,4 \%$, yang tidak melakukan sarapan sebanyak $26,6 \%$ dan anak yang mempunyai tingkat kesegaran jasmani yang kurang sebanyak 11,3\% sedangkan tingkat kesegaran jasmani baik sebanyak $88,7 \%{ }^{6}$

Sarapan juga berpengaruh untuk kerja sistem tubuh anak dan status gizi terutama dalam hal pemenuhan zat gizi yaitu melalui pemenuhan zat gizi dengan terpenuhinya zat gizi dalam tubuh maka dapat menunjang pertumbuhan fisik, pertumbuhan otak, dan kemampuan kerja otak. Cadangan energi yang rendah akan berdampak pada penurunan produktivitas dan prestasi belajar pada anak sekolah sebagai akibat kekurangan gizi. $^{1,7}$

Bagi anak yang tidak sarapan mempunyai risiko terhadap status gizi. Anak yang tidak sarapan akan cenderung mengkonsumsi makanan jajanan. Jajan yang terlalu sering dapat mengurangi nafsu makan anak di rumah. Selain itu banyak makanan jajanan yang kurang memenuhi syarat kesehatan sehingga akan mengganggu kesehatan anak. Sebagian besar makanan jajanan terbuat dari karbohidrat sehingga lebih tepat sebagai snack antar waktu makan, bukan sebagai pengganti makanan utama. Makanan jajanan yang dibeli atau dikonsumsi banyak mengandung energi dan lemak seperti makanan gorengan dan lain-lain yang berpeluang menjadi gemuk atau status gizi lebih, sedangkan kalau makanan jajanan yang dibeli seperti makanan ringan, es, permen maka anak ini merupakan anak yang rendah gizi terutama kalori sehingga kalau ini dikonsumsi tiap hari maka anak akan menjadi gizi kurang. Penelitian yang dilakukan di Sekolah Dasar Saudi Arabia menunjukkan hasil bahwa yang meniadakan sarapan sebanyak 25\%, yang sarapan sebanyak $40,83 \%$, yang kelebihan berat badan sebanyak $20,4 \%$, berat badan normal sebanyak $66,7 \%$ dan berada di bawah masih berat badan normal sebanyak 7,5\%. ${ }^{7}$

Berdasarkan survey yang dilakukan Dinas Kesehatan Kota Semarang menunjukkan prevalensi anak sekolah dasar yang mempunyai berat badan lebih $16,1 \%$ pada anak laki-laki sedangkan berat badan lebih pada perempuan $17,6 \%{ }^{8}$ Hasil survey awal di SD Negeri
Padangsari 02 Banyumanik, didapatkan hasil bahwa anak - anak di SD tersebut jarang melakukan sarapan dan lebih menyukai makan jajanan di sekitar sekolah serta kurangnya aktivitas fisik yang berdampak pada kelebihan berat badan, dimana berdasarkan penelitian awal 18,3\% anak SD tersebut mengalami gizi lebih dan yang melakukan sarapan 27,1\% dari 90 anak. Berdasarkan latar belakang tersebut, maka peneliti ingin mengetahui lebih lanjut mengenai hubungan kebiasaan sarapan dengan kesegaran jasmani dan status gizi pada anak sekolah dasar di SD Negeri Padasangsari 02 Banyumanik.

\section{METODA}

Penelitian ini merupakan penelitian observasional dengan menggunakan pendekatan cross sectional yang dilaksanakan di Sekolah Dasar Negeri Padangsari 02 Banyumanik Semarang. Populasi dalam penelitian ini adalah murid Sekolah Dasar Negeri Padangsari 02 kelas IV dan V. Besar subyek yang dibutuhkan dalam penelitian ini sebanyak 56 anak. Subyek diambil dengan cara simple random sampling.

Variabel dependent adalah kebiasaan sarapan sedangkan variabel independent adalah kesegaran jasmani dan satatus gizi. Kebiasaan sarapan dilihat dari jumlah hari dalam satu minggu responden mengkonsumsi sarapan di pagi hari (pukul 06.00 - 10.00 WIB) selain itu dilihat dari nilai kalori sarapan tersebut yaitu dikatakan sarapan jika mempunyai sumbangan sebanyak $20 \%$ dari konsumsi sehari.

Kesegaran jasmani ditentukan berdasarkan perhitungan menggunakan Harvard Step Test yang dinyatakan dalam bentuk bpm denyut nadi yaitu dengan cara subyek melakukan gerakan naik turun bangku Harvard setinggi $30 \mathrm{~cm}$ selama 3 menit, setelah sampel naik turun bangku Harvard subyek istirahat selama 1 menit. Kemudian subyek diukur denyut nadinya selama 30 detik, denyut nadi diukur sebanyak 3 kali pengukuran.

Status gizi ditentukan berdasarkan pengukuran antropometri (berat badan dan tinggi badan) dengan menggunakan BMI (Body Massa Index) yang dikonversikan ke dalam nilai z-score IMT/U untuk anak laki-laki dan perempuan usia 519 tahun dengan skor simpang baku (zscore) menggunakan program WHO Anthro Plus 2007.

Analisis data untuk mengetahui hubungan antara status gizi dengan kesegaran jasmani dan status gizi menggunakan uji Korelasi Spearman 
yang sebelumnya diuji normalitas datanya dengan uji Kolmogorov-Smirnov.

\section{HASIL PENELITIAN}

A. Karakteristik Subjek Penelitian

Subyek penelitian sebanyak 56 anak SD dari kelas IV dan $\mathrm{V}$ dengan karakteristik subjek sebagai berikut :

Tabel 1. Karakteristik Subjek

\begin{tabular}{lcc}
\hline & $\mathrm{n}$ & $\%$ \\
\hline Jenis kelamin & & \\
$\quad$ Laki-laki & 24 & 42,9 \\
$\quad$ Perempuan & 32 & 57,9 \\
\hline Total & 56 & 100 \\
\hline Usia & & \\
$\quad 8-9$ tahun & 18 & 32,2 \\
$\quad 10-11$ tahun & 38 & 67,8 \\
\hline Total & 56 & 100 \\
\hline
\end{tabular}

Tabel 1 menunjukkan $57,9 \%$ berjenis kelamin perempuan dan kelompok usia paling banyak $67,8 \%$ masuk dalam kelompok usia 10 - 11 tahun.
B. Sarapan

Sarapan yang dilakukan subjek dapat dilihat dalam tabel 2.

Tabel 2. Distribusi frekuensi kebiasaan sarapan

\begin{tabular}{ccc}
\hline Kebiasaan Sarapan & n & \% \\
\hline Setiap hari (7 hari) & 8 & 14,3 \\
4-6 hari & 28 & 50,0 \\
$1-3$ hari & 17 & 30,4 \\
Tidak pernah (0 hari) & 3 & 5,4 \\
\hline Total & 56 & 100 \\
\hline
\end{tabular}

Tabel 2 menunjukkan kebiasaan sarapan yang dilakukan oleh subjek paling banyak selama 4 - 6 hari sebanyak 28 anak (50\%). Jenis sarapan yang biasa dikonsumsi subjek dapat dilihat pada tabel 3 .

Tabel 3. Jenis sarapan yang biasa dikonsumsi

\begin{tabular}{ccc}
\hline Jenis Sarapan & $\mathbf{n}$ & $\mathbf{\%}$ \\
\hline Nasi goreng & 14 & 25,0 \\
Mie instant & 5 & 8,9 \\
Bubur ayam & 6 & 10,7 \\
Soto & 5 & 8,9 \\
Nasi telur & 6 & 10,7 \\
Nasi ayam goreng & 4 & 7,1 \\
Roti bolu & 2 & 3,6 \\
Donat & 3 & 5,4 \\
Roti bakar & 8 & 14,3 \\
Susu & 3 & 5,4 \\
\hline Total & 56 & 100
\end{tabular}

Tabel 3 menunjukkan bahwa sarapan yang dikonsumsi subjek lebih banyak nasi goreng sebanyak 14 anak (25\%). Jika dilihat dari cara

mendapatkan sarapan, selengkapnya dapat dilihat pada tabel 4 .

Tabel 4. Cara mendapatkan sarapan

\begin{tabular}{ccc}
\hline Cara mendapatkan sarapan & n & \% \\
\hline Dibuat sendiri dirumah & 31 & 55,4 \\
Beli di luar rumah & 25 & 44,6 \\
\hline Total & 56 & 100 \\
\hline
\end{tabular}


Tabel 4 dapat diketahui bahwa 55,4\% anak SD mendapatkan sarapan yang dibuat sendiri dirumah. Rerata total energi yang dikonsumsi dari sarapan sebesar $328,18 \pm 91,54 \mathrm{kkal}$. Rerata tersebut dapat memberikan sumbangan energi total, adapun hasilnya sebagai berikut :

Tabel 5. Sumbangan Energi

\begin{tabular}{ccc}
\hline Sumbangan Energi & n & \% \\
\hline$<20 \%$ & 34 & 60,7 \\
$\geq 20 \%$ & 22 & 39,3 \\
\hline Total & 56 & 100 \\
\hline
\end{tabular}

Tabel 5 menunjukkan bahwa sumbangan sarapan yang dilakukan oleh subjek paling banyak memberikan sumbangan energi total $<20 \%$ sebanyak 34 anak $(60,7 \%)$.

\section{Kesegaran Jasmani}

Kesegaran jasmani yang dilakukan subjek dapat dilihat dalam tabel 6 .

Tabel 6. Distribusi frekuensi kesesegaran jasmani

\begin{tabular}{ccc}
\hline Kesegaran jasmani & n & \% \\
\hline$\leq 64$ & 10 & 17,9 \\
$65-79$ & 32 & 57,1 \\
$\geq 80$ & 14 & 25,0 \\
\hline Total & 56 & 100 \\
\hline
\end{tabular}

Tabel 6 menunjukkan subjek yang paling banyak memiliki kesegaran jasmani yang baik dengan nilai denyut nadi 65-79 bpm sebanyak 32 anak $(57,1 \%)$ dan nilai denyut nadi $\geq 80$ bpm sebanyak 14 anak $(25 \%)$.

\section{Status Gizi}

Status gizi responden dilihat berdasarkan $z$-score IMT/U, adapun hasilnya sebagai berikut :

Tabel 7. Karakteristik status gizi

\begin{tabular}{cccc}
\hline Karakteristik subjek & Min & Max & Median \\
\hline BB & 19,3 & 61,1 & 37,7 \\
TB & 113,5 & 155,5 & 137,0 \\
Z-score (IMT/U) & $-2,68$ & 2,93 & 1,24 \\
\hline
\end{tabular}

Tabel 7 menunjukkan hasil bahwa median $z-\quad$ score tersebut dikategorikan maka hasilnya score responden sebesar 1,24. Jika median $z^{-}$dapat dilihat pada tabel 8 .

Tabel 8. Distribusi frekuensi status gizi

\begin{tabular}{ccc}
\hline Status Gizi & n & \% \\
\hline Kurus & 1 & 1,8 \\
Normal & 23 & 41,1 \\
Overweight & 19 & 33,9 \\
Obesitas & 13 & 23,2 \\
\hline Total & 56 & 100
\end{tabular}

Tabel 8 didapatkan hasil 23,2\% anak mengalami obesitas dan 33,9\% anak mengalami overweight.

E. Hubungan antara Kebiasaan sarapan dengan kesegaran jasmani

Hasil uji hubungan antara kebiasaan sarapan dengan kesegaran jasmani dapat dilihat pada gambar

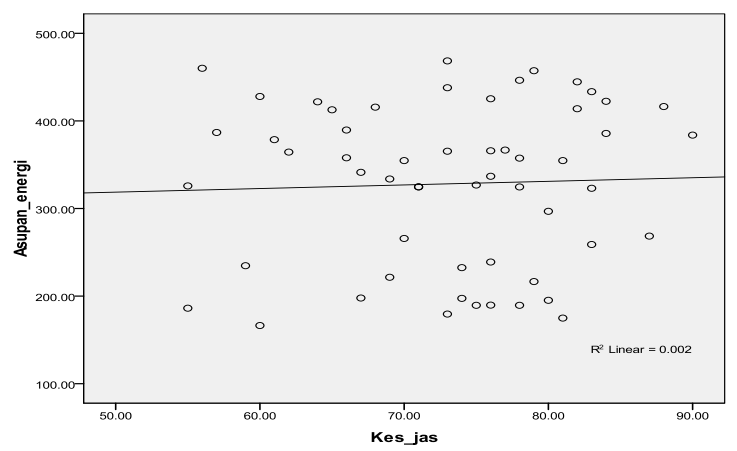


$p=0,372$

$\mathrm{r}=\mathbf{0 , 0 4 5}$

\section{Gambar 1. Hubungan Kebiasaan Sarapan dengan Kesegaran Jasmani}

Gambar 1 menunjukkan hasil bahwa tidak ada hubungan antara kebiasaan sarapan dengan kesegaran jasmani $(\mathrm{p}=0,372 ; \mathrm{r}=$ $0,045)$

\section{F. Hubungan antara kebiasaan sarapan dengan status gizi}

Hasil uji hubungan antara kebiasaan sarapan dengan kesegaran jasmani dapat dilihat pada gambar

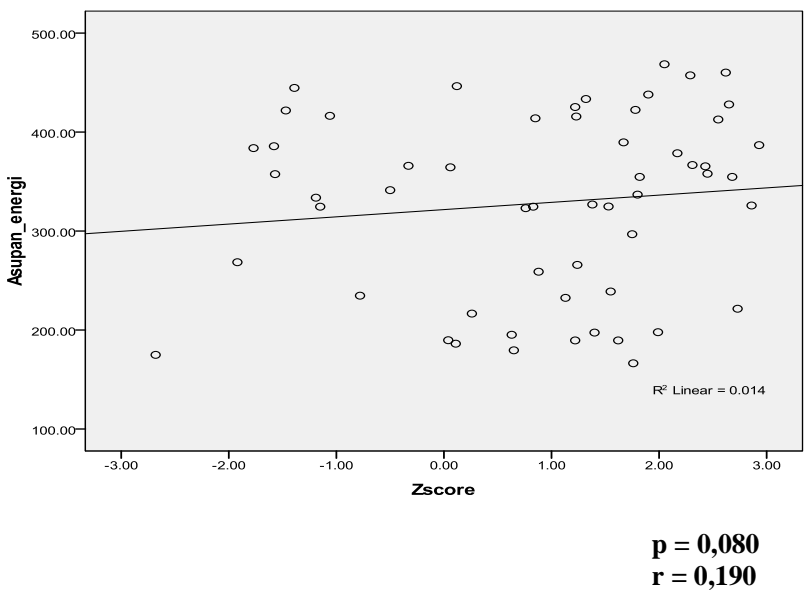

\section{Gambar 2. Hubungan Kebiasaan Sarapan dengan Status Gizi}

Gambar 2 menunjukkan hasil bahwa tidak ada hubungan antara kebiasaan sarapan dengan kesegaran jasmani $(p=0,080 ; r=0,190)$.

\section{PEMBAHASAN}

\section{Karakteristik Subyek Penelitian}

Hasil penelitian menunjukkan anak yang jarang sarapan sebanyak 17 (30,4\% anak) dan tidak pernah sarapan sebanyak $3 \quad(5,4 \%$ anak $)$ alasan kenapa mereka tidak sarapan berdasarkan hasil wawancara yang didapat adalah karena tidak sarapan itu merupakan hal yang biasa, tidak ada selera makan, tidak sempat sarapan karena bangunnya kesiangan. Hasil tersebut sama dengan penelitian yang dilakukan Triyanti di SD Citarum 01,02,03 dan 04 Semarang yang menunjukkan hasil masih terdapat $34,83 \%$ anak yang jarang sarapan dan 2,5\% anak tidak pernah sarapan.

Sarapan yang baik mengandung energi sebesar 20\% dari kebutuhan sehari. Hasil penelitian ini hanya $22(33,9 \%)$ anak dari sampel yang dapat memenuhi ketentuan tersebut dan sisanya $34 \quad(60,7 \%)$ anak tidak memenuhi ketentuan tersebut. Hasil ini sama dengan penelitian Melvin di SMP 26 Semarang tahun 2012 yang menunjukkan asupan energi sarapan yang < $20 \%$ sebanyak $64,3 \%$ anak. $^{10}$

Jenis makanan sarapan yang dilakukan subjek yaitu mie instant, nasi goreng, bubur ayam, soto, nasi telur, nasi ayam goreng, kue donat, roti bolu dan roti bakar dan susu. Jenis sarapan ini jika dilihat dari nilai gizinya cukup atau padat energi tetapi ada yang beranggapan bahwa minum susu sudah termasuk sarapan padahal jika dilihat dari definisi sarapan adalah makanan yang dimakan pada pagi hari sebelum beraktivitas yang terdiri dari makanan pokok dan lauk pauk atau makanan kudapan dengan waktu sarapan dimulai dari pukul 06.00 sampai dengan pukul $10.00 .{ }^{1}$

Hasil penelitian menunjukkan jumlah subyek yang memiliki nilai kesegaran jasmani kurang sebanyak $10 \quad(17,9 \%)$ anak dan nilai kesegaran jasmani sedang sebanyak $32(57,1 \%)$ anak. Hasil ini sama dengan penelitian Nurul Hidayati di SD Singosari tahun 2012 yang menunjukkan $6,7 \%$ subyek mempunyai kesegaran jasmani sedang dan 63,3\% subyek mempunyai kesegaran jasmani kurang. ${ }^{6}$

Penelitian didapatkan hasil bahwa 33,9\% anak mengalami overweight dan 23,2\% anak mengalami obesitas. Penelitian ini sama dengan penelitian yang dilakukan Yuni di SD Pedurungan yang menyatakan 40,7 \% anak memiliki status gizi lebih. ${ }^{11}$ Hasil RISKESDAS 2013 menunjukkan prevalensi overweight dan obesitas pada anak sekolah (5-12 tahun) masih tinggi sebesar 18,8\% dan $8,8 \% .{ }^{12}$ Hal ini menunjukkan bahwa gizi lebih masih menjadi masalah pada anak sekolah dasar yang belum tertangani dengan baik dan prevalensinya masih cukup tinggi setiap tahunnya.

\section{Hubungan Kebiasaaan Sarapan dengan Kesegaran Jasmani}

Hasil penelitian menunjukkan tidak ada hubungan antara kebiasaan sarapan dengan kesegaran jasmani. Hasil ini sesuai dengan penelitian Nugrahaini di SD Negeri I Kartasura tahun 2009 yang menunjukkan tidak ada hubungan kebiasaan sarapan dengan status gizi. ${ }^{13}$

Tidak adanya hubungan dalam penelitian disebabkan karena kebiasaan sarapan hanya dihitung dari jumlah hari anak sarapan selama satu minggu tidak dilihat asupan energinya sehingga tidak mempengaruhi kesegaran jasmani, ternyata setelah dilihat dari asupan energinya juga tidak berhubungan karena ada faktor lain yang mempengaruhi kesegaran jasmani yang tidak diteliti dalam penelitian ini antara lain umur, aktivitas fisik, dan kesehatan badan. 
Aktivitas fisik merupakan gerakan yang dilakukan oleh tubuh dan sistem penunjangnya yang biasanya dilakukan dalam kehidupan seharihari. Kesehatan anak akan mempengaruhi tingkat kesegaran jasmani, sebab ketidaksempurnaan fungsi tubuh tertentu akan mempengaruhi kemampuan tubuh untuk melakukan aktivitas baik disekolah maupun di luar sekolah. ${ }^{13}$

Sarapan sangat penting untuk anak SD karena jika tidak sarapan akan mempengaruhi tingkat prestasi belajar yang berdampak pada nilai yang menurun dan kehadiran sekolah serta berdampak pada aktivitas fisik yang berpengaruh pada kesegaran jasmani anak, selain itu melewatkan sarapan secara terus menerus juga akan berpengaruh pada status gizi yang berpeluang menjadi kelebihan berat badan atau obesitas. ${ }^{14}$ Anak yang melewatkan sarapan akan cepat merasa lelah dan lemas dalam melakukan kegiatan dan aktivitas fisik serta penurunan daya pemikirannya karena kurangnya zat-zat makanan atau intake pangan yang masuk ke dalam tubuh dan gizi yang cukup. Aktivitas yang cukup dapat meningkatkan penggunaan lemak daripada $\mathrm{KH}$, selain itu latihan fisik pada seseorang memetabolisme lebih banyak lemak yang diberikan untuk energi expenditure dibandingkan dengan yang tidak latihan fisik. ${ }^{15-18}$ Asupan gizi yang baik sangat diperlukan untuk memperoleh kondisi fisik yang baik. Dimana kondisi baik tersebut digunakan untuk mempertahankan derajat kesegaran jasmani. Latihan jasmani bila dilakukan secara teratur dapat meningkatkan kesegaran jasmani serta daya tahan anak. $^{19}$

\section{Hubungan Kebiasaan Sarapan dengan Status Gizi}

Penelitian ini tidak didapatkan hubungan antara kebiasaan sarapan dengan status gizi. Hasil ini sesuai dengan penelitian Evan Regar di SD Jakarta tahun 2012 yang menunjukkan tidak ada hubungan kebiasaan sarapan dengan status gizi. ${ }^{20}$

Tidak adanya hubungan kebisaan sarapan dengan status gizi karena status gizi dipengaruhi oleh asupan gizi terhadapa kebutuhan dalam sehari, bukan dari jumlah berapa kali sarapan tetapi setelah dilihat dari asupan energi perhari ternyata juga tidak berhubungan dikarenakan perhitungan asupan energi yang tidak tepat. Diduga terdapat pula pengaruh faktor perancu seperti keberadaan penyakit yang turut mempengaruhi status gizi namun tidak dapat ditentukan pada penelitian ini. Penyebab lainnya adalah perbedaan metode pengukuran asupan gizi, perbedaan kelompok usia subyek penelitian, serta faktor lain yang berbeda anatara satu penelitian dengan penelitian lainnya.

Pengaruh sarapan terhadap satatus gizi yaitu melalui pemenuhan kebutuhan zat gizi karena sarapan dapat memberikan sumbangan zat gizi perharinya. Anak yang tidak sarapan maka akan berisiko defisiensi zat gizi. Jika hal ini berlangsung lama akan berpengaruh terhadap status gizinya. Sarapan yang baik akan memberikan sumbangan energi sebanyak $20 \%$. Status gizi yang baik atau optimal akan berpengaruh bila tubuh memperoleh cukup zat gizi yang digunakan secara efisien, sehingga memungkinkan pertumbuhan fisik, pertumbuhan otak, kemampuan kerja otak. Seorang anak yang sehat dan normal akan tumbuh sesuai dengan potensi genetik yang dimilikinya, tetapi pertumbuhan ini juga akan dipengaruhi oleh intake gizi yang dikonsumsi dalam bentuk makanan. Cadangan energi yang rendah dan tinggi lemak akan berdampak pada penurunan produktivitas dan prestasi belajar pada anak sekolah sebagai akibat kekurangan dan kelebihan zat gizi. Kekurangan atau kelebihan zat gizi akan mempengaruhi status gizi anak. ${ }^{1,9}$

Gizi kurang dan gizi lebih terjadi jika terdapat ketidakseimbangan antara konsumsi energi dan pengeluaran energi. Makanan dengan kepadatan energi yang tinggi (banyak mengandung lemak atau gula yang ditambahkan dan kurang mengandung serat) juga akan berpengaruh pada keseimbangan energi. Gizi kurang disebabkan karena kurangnya asupan makanan sumber kalori protein dalam waktu yang lama secara terus menerus, yang biasanya disertai dengan penyakit infeksi. Kekurangan asupan makanan mengakibatkan daya tahan tubuh sangat lemah sehingga mudah terkena penyakit infeksi. ${ }^{9}$

\section{SIMPULAN}

Subjek yang melakukan sarapan setiap hari (selama satu minggu) sebanyak 8 anak $(14,3 \%)$ dan subjek yang melakukan sarapan sering (4-6 hari) sebanyak 28 anak (50\%). Sumbangan energi subjek dari sarapan < 20\% sebanyak 34 anak $(60,7 \%)$. Subjek yang overweight dan obesitas cukup tinggi sebanyak 19 anak $(33,9 \%)$ dan 13 anak $(23,2 \%)$. Rerata kebiasaan sarapan subyek yaitu sebesar 4,28 $\pm 1,84$ kali/minggu. Rerata sumbangan energi sarapan subyek yaitu sebesar $34,01 \pm 9,09$ persen. Rerata kesegaran jasmani subyek yaitu sebesar $73,08 \pm 8,81 \mathrm{bpm}$. Rerata $z$ -

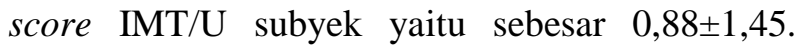
Tidak ada hubungan antara kebiasaan sarapan dengan kesegaran jasmani secara statistik. Tidak 
ada hubungan antara kebiasaan sarapan dengan status gizi secara statistik.

\section{SARAN}

Perlu dilakukan penyuluhan dan peningkatan pemahaman tentang pentingnya sarapan karena masih ada anak yang jarang sarapan dan tidak pernah sarapan sehingga perlu diadakan konseling rutin oleh guru bimbingan konseling sehingga tidak berpengaruh pada status gizi juga tingkat kesegaran jasmani anak, kepada peneliti lain agar memeneliti faktor lain (aktivitas fisik, usia dan kesehatan badan) yang dapat mempengaruhi kebiasan sarapan dengan kesegaran jasmani dan status gizi dengan jumlah subyek yang lebih besar.

\section{DAFTAR PUSTAKA}

1. Thompson J, Manore M Nutritional an Applied Approach. Second Edition. Pearson Benjamin Cummings 2010,p.528-569, 651.

2. Moehji, Sjahmien. Ilmu Gizi 2 Penanggulangan Gizi Buruk. Jakarta: PT Bhratara Niaga Media, 2009.

3. Ali, Khomsan. Pangan dan Gizi untuk Kesehatan. Jakarta: PT. Rajagrafindo. Persada; 2003.

4. Utter, J., Scragg, R., Mhurchu, C. \& Schaaf, D. At home Breakfast Consumption Among New Zealand Children: Associations With Body Mass Index And Related Nutrition Behaviors. Journal of the American Dietetic Association 2007, 107, 570-576.

5. Mintarti, Mintarti. Hubungan Antara Status Gizi dan Tingkat Kesegaran Jasmani Siswa Kelas IV, V dan VI SD Negeri II Pacekelan Kecamatan Purworejo. Skripsi, UNY; 2012.

6. Sis Yulia A. Hubungan Tingkat Konsumsi Energi Dengan Kesegaran Jasmani Anak Kelas IV dan V SD Negeri Singosari 01 Kecamatan Semarang Selatan; Skripsi Akademi Gizi Muhamadiyah; 2001.

7. Latifah M Al-Oboudi. Impact Of Breakfast Eating Pattern On Nutritional Status, Glucose Level, Iron Status In Blood, And Test Grade Among Upper Primary School Girls In Riyadh City, Saudi Arabia. Pakistan Journal Of Nutrition 9 (2): 106-111, 2010.

8. DINKES,2010. Profil Kesehatan Kota Semarang. Semarang.

9. SARI. Triyanti. Hubungan Antara Kebiasaan Makan Pagi dengan Prestasi Belajar pada Anak Sekolah Dasar Kelas V di Sekolah Dasar Negeri Citarum. Skripsi, UGM; 2005.

10. Melvin. Hubungan Antara Asupan Energi Sarapan Dengan Kebugaran Jasmani Siswi Kelas VII di SMP Negeri 26 Semarang. Skripsi, UNNES; 2012.

11. Yuni. Hubungan Antara Kebiasaan Sarapan dan Kebiasaan Jajan dengan Status Gizi Pada Anak
Sekolah Dasar Di Kecamatan Pedurungan Kota Semarang. Skripsi, UNDIP; 2012.

12. Departemen Kesehatan Republik Indonesia. Laporan Hasil Riset Kesehatan Dasar (RISKESDAS) Inonesia tahun 2013. Jakarta : Badan Penelitian dan Pengembangan Kesehatan.

13. Nugrahaini. Hubungan Tingkat Konsumsi Karbohidrat, Protein Dan Lemak Dengan Kesegaran Jasmani Anak Sekolah Dasar di SD N Kartasura I. Skripsi, UMS; 2009.

14. Sri Hastuti. Hubungan Status Gizi dengan Tingkat Kesegaran Jasmani Anak Sekolah Dasar di SD Negeri MAjaro 1 Kec Tawangsari Kab Sukoharjo. Skripsi, UNDIP; 2003.

15. Djoko Pekik Arianto. Panduan Gizi Lengkap Keluarga dan Olahragawan. Yogyakarta : Andi Ofset; 2007. Hal.57-112.

16. Gibson Rosalind S. Principle Nutritional Assesment. New York; Oxford University Press; 2005.p.294.

17. Mahan LK, Escot-Stump S. Nutrition in Adeolescent and Krause's Food, Nutrition and Diet Therapy. Philadelphia: WB Saunders Company. 2004 : 218-221.

18. Dehghan M, Danesh NA, Merchan AP. Childhood Obesity, Prevalence and Preventation, Journal of Nutrition 2005; 4 : 24.

19. Hill JO, Edward L, Melanson, Wyatt HT Dietary Fat Intake and Regulation of energy Balance. ImplicationFor Obesity. Journal of Nutrition. 2000; $130: 248 \mathrm{~S}-8 \mathrm{~S}$.

20. Evan Regar. Hubungan Kecukupan Asupan Energi dan Makronutrien dengan Status Gizi Anak Usia 57 Tahun di Kelurahan Kampung Melayu, Jakarta Timur. Skirpsi, UI; 2012. 